\title{
An assessment of phytoremediation capacity of Eichhornia crassipes and Typha capensis for the removal of total dissolved solids in plastic recycling industry wastewater.
}

\author{
N. Mudavanhu ${ }^{* 1}$, A. Ndeketeya ${ }^{2}$ and N. Masaya ${ }^{3}$.

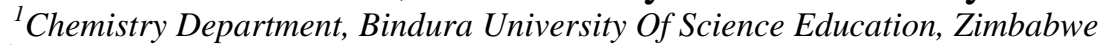 \\ ${ }^{2}$ Agriculture Department, Bindura University Of Science Education, Zimbabwe \\ ${ }^{3}$ Safety Health and Environmental Management Department, Bindura University Of Science Education, \\ Zimbabwe
}

\begin{abstract}
The phytoremediation potential of two macrophytic plants, E.crassipes and T.capensis were evaluated for their capacity to remove total dissolved solids (TDS) from a plastic recycling industrial effluent. The effluent was collected from a plastics recycling company in Harare, Zimbabwe. Experimental design was used in the research and the pants were grown in $2.5 \mathrm{~L}$ plastic pots. The experiment consisted of 8 treatments with replicates. TDS, electrical conductivity and $\mathrm{pH}$ were measured every day for 15 days and proline accumulation in plant leaves was analyzed every 2 days alongside wastewater treatment. A t-test analysis was used for testing the data for significance difference. Result show that T.capensis had reduced TDS by $77.3 \%$ in diluted and $69.3 \%$ in undiluted effluent while E.crassipes, also remarkable TDS reduction of $65.1 \%$ in diluted and $57.8 \%$ in undiluted effluent. Statistical analysis showed no significant difference at $p<0.05$ for the two plants. TDS reduction by both plants was accompanied by an increase in $p H$ and decrease electrical conductivity. Waste water only and wastewater + soil controls showed a TDS concentration decreased of $5.0 \%$ and $42.1 \%$ after treatment which may be due to microbial activity. Proline accumulation for both plants in undiluted effluent (30.05\% in Typha spp. and 19.04\% in Eichhornia spp.) is an indication of high TDS stress capability of the two plants. The proline concentration results show significant difference between day 0 and day 6 at $p<0.05$.
\end{abstract}

Keywords: Phytoremediation, Plastic effluent, Total dissolved solids, Eichhornia crassipes, Typha capensis, Proline.

\section{Introduction}

Water pollution is considered to be one of the most dangerous hazards affecting both developing and developed countries due to industrialization and subsequent production of a variety of chemicals [1]. The wastewater effluent which is generated from a number of industries usually contains high total dissolved solids (TDS) concentration [2]. According to Saiyood et al [3], the constituent of solutes in TDS are either inorganic, including cations (sodium, calcium, magnesium, and potassium), or anions (carbonates, nitrates, bicarbonate, and chloride, sulfate). Electrical conductivity (property closely related to TDS) of solutions depends upon the concentrations and mobilities of these ions [4]. Electrical Conductivity is a surrogate measure of total dissolved solids with established stable relationship [5].In natural water case studies, a conversion factor range of 0.540.96 was established, with most falling between 0.55 and 0.75 [6].These inorganic dissolved solids are complex to remove and their high concentration can be toxic to living organisms [2]. TDS causes toxicity through increase in salinity to biotic communities, limit biodiversity and cause acute or chronic effects at specific life stages of plants [7]. Therefore, TDS of industrial effluent should be reduced to acceptable levels before the effluent is discharged into rivers, other water bodies or municipal sewers. The Zimbabwean Environmental Management Agency has set normal (blue region) conductivity, $\mathrm{pH}$ and TDS limits of $\leq 1000 \mu \mathrm{S} / \mathrm{cm}, 6-9$ and $\leq 500 \mathrm{mg} / \mathrm{L}$ respectively. Only waste water meeting these and other associated parameters can be discharged as effluent. Most companies struggle to reduce the physico - chemical properties of to these levels due to large quantities of effluent and the costs involved.

The commonest physical-chemical methods that are used to remove TDS during industrial wastewater treatment are: reverse osmosis, electrophoresis and distillation [2]. These methods require high energy and large capital investment. Phytoremediation; the process of using plants (phyto) to clean up (remediate) water and soil; is an alternative method for TDS removal, as it is well-known to be a sustainable and cost-effective method [8; 9]. Research on phytoremediation of wastewater to date involves, growing of phytoremediation plants especially macrophytic, in a bed of inert granular substrate using hydroponic or aeroponic techniques [10]. Plant root harvesting equipment and techniques are being evaluated and modified as necessary for the use with phytoremediation plants [10]. The efficiency of TDS removal by plants mainly depends on the tolerance of 
plants to the wastewater and their TDS uptake capability. Macrophytic plants are expected to have the ability to reduce the TDS contaminated plastic effluent [9] because they are naturally found in polluted water bodies. Typha and Eichhornia spp are macropyhtes that are locally available in abundance and underutilized. Eichhornia spp are actually considered a nuisance as they have invaded lakes and rivers.

High TDS concentrations pose a danger in survival of potential phytoremediation plants. An important condition during phytoremediation is plant survival under stressful conditions. Plants have various mechanisms to counter environmental stress [11]. Proline (Fig.1) a proteinogenic secondary amino acid, [12] is well known for protecting plant cell by maintaining the osmotic balance and protection of subcellular structures when salt levels and temperatures are unfavorable [12]. Plants experiencing salinity or water stress in their root zone respond physiologically by regulating their metabolism of proline to adjust to the adverse conditions as water shortage and salinity.

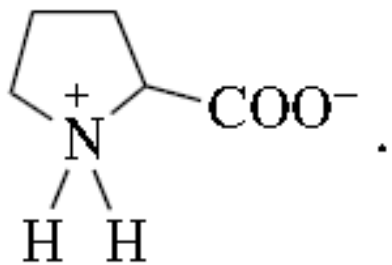

Figure 1: Chemical structure of proline [12]

Similarly, accumulation of sugars seem also to be play a similar role in the regulation of cytoplasmic osmotic potentials [13]. Proline and sugars stabilizes membranes and proteins and increase osmotic potential by their accumulationin the cytoplasm, while mineral ions are localized in the vacuole. [15].These compounds have an important role to play in plant ability to fight to environmental stress. Proline can be used as a signal of plant salt stress hence uptake of salts from high TDS waters. Since proline is known to accumulate in plants subjected to unfavorable environmental conditions, the concentrations of this amino acids has been used in several experiments as a measure of stress imposed on plants[3].

At a local plastic recycling company waste water is treated by coarse screening and sedimentation processes. After these two physical processes the water has been found to have high TDS concentrations. Environmental regulatory authorities have recommended that the effluent be further treated to reduce TDS. The study is therefore aimed at evaluating two well-known macrophytic plants, the free floating Eichhornia crassipes and emerging Typha capensis as candidates for uptake of TDS wastewater effluent. These plants are evaluated for both their capability to reduce TDS and ability to withstand the saline conditions by measuring proline accumulation.

\subsection{Waste water sampling}

II. Methodology

The effluent wastewater was collected from the third settling tank which discharges wastewater to the municipal sewer by grab sampling. The containers used were washed using a dishwasher before rinsing with municipal water and lastly with distilled water. Wastewater was collected in 5 litres polyethylene containers filled to $3 / 4$ levels. Immediately after sample collection the plastic containers were sealed with their caps, and each container was labelled accordingly and sent to the laboratory in plastic cooler boxes. Samples were kept out of direct sunlight and were refrigerated at $4^{\circ} \mathrm{C}$ in the laboratory before analysis. Water quality parameters analysed included $\mathrm{pH}$, TDS and E.C.

\subsection{Pre - experiment plant treatment}

Two macrophytic plants were used: a free floating plant, Eichhornia crassipes and an emergent plant Typha capensis.These plants were taken from nearby Pote River in Bindura. The plant species were carefully harvested and washed thoroughly with tap water. Eichhornia crassipes plant species were then propagated hydroponically in a pond for five days. For Typha capensis, 2 plants were transplanted into plastic pots with $1.5 \mathrm{~kg}$ soil and grown for five days.

\subsection{E.crassipes and T. capensis experimental setup.}

After five days Eichhornia crassipes plants were rinsed using distilled water and then weighed and labelled accordingly. Plastic pots with the carrying capacity of $2.5 \mathrm{~L}$ were used in the experiment. Two plants of nearly the same mass $(50 \mathrm{~g})$ were put in each pot. Two- litres of wastewater were used for $E$. crassipes and no soil was added in its experiments since it is a free floating plant. For T. capensis since it was growing in soil 
(analyzed for $\mathrm{pH}(5.39)$ and $\mathrm{EC}(1.08 \mu \mathrm{S} / \mathrm{cm})$ before the experiment) already as an emergent plant 1.5 litres of waste water was added. Table 1 shows the experiment treatments used.

Table 1: Experimental setup

\begin{tabular}{|l|l|}
\hline Treatments & Controls \\
\hline Undiluted wastewater + E.crassipes & Undiluted wastewater only \\
Undiluted wastewater+ T. capensis + soil & Wastewater + soil \\
$50 \%$ diluted wastewater+E.crassipes & \\
$50 \%$ diluted wastewater + T. capensis+ soil & \\
Distilled water + E.crassipes & \\
Distilled water + T.capensis + soil & \\
\hline
\end{tabular}

The pots were placed in outdoor environment with temperature ranging from $25.9-30^{\circ} \mathrm{C}$. The experiment was observed every day for two weeks, the water and leaves were collected after every two days (between 7 and $8 \mathrm{am}$ ) for physiochemical properties and proline content analysis respectively. When the water level was reduced due to evaporation, an average of $350 \mathrm{mls}$ of distilled water were added per day to keep a constant level of water in the experiments.

\subsection{Determination of TDS, EC and $\mathrm{pH}$.}

TDS and EC was analyzed using TDS/EC meter (ADWA-AD3000). The $\mathrm{pH}$ was also analyzed using $\mathrm{pH}$ meter (ADWA-AD1040).

\subsection{Soil analysis}

Soil was analyzed for $\mathrm{pH}$ and $\mathrm{EC}$ before the experiment. The soil $\mathrm{pH}$ was determined by weighing $15 \mathrm{~g}$ of soil and mixed with $75 \mathrm{ml}$ of Calcium Chloride and the sample was agitated for 30 minutes before it was recorded using the $\mathrm{pH}$ meter. To determine for EC a sample of $15 \mathrm{~g}$ soil, the soil was mixed with $75 \mathrm{ml}$ distilled water and agitated for 30 minutes and the EC meter was used for recordings.

\subsection{Analysis of Proline Content in plant leaves.}

Proline content was analyzed as described by [13] minor modifications. Briefly, 500mg of Eichhornia crassipes and Typha capensis fresh tissue sample leaf was ground in a mortar and homogenized in $10 \mathrm{~mL}$ of $3 \%$ sulphosalicylic acid and was filtered through Whatman's no. 2 filter paper. Then two milliliters of the filtered sample was gently mixed with $2 \mathrm{~mL}$ of acid ninhydrin and $2 \mathrm{~mL}$ of glacial acetic acid in a test tube. Afterwards the mixture was kept in the water bath at $100^{\circ} \mathrm{C}$ for $1 \mathrm{hr}$ to develop the color. After $1 \mathrm{hr}$ the test tube where then cooled on ice and $4 \mathrm{~mL}$ of toluene was added to separate chromophores. The absorbance was measured at $520 \mathrm{~nm}$ with spectrophotometer (Genesys, model 10S, UK). The concentration was obtained using the standard method.

\subsection{Statistical analysis}

Differences between means at the confidence interval $(\mathrm{p}<0.05)$ level were considered significant.

\section{Results and Discussion}

The phytoremediation capability was based on the plants' TDS percent mass removal from waste water. The TDS, Electrical conductivity (EC) and $\mathrm{pH}$ of the effluent and control samples was analyzed before and during treatment with the macropyhtes. The wastewater was found to have $1591 \mathrm{mg} / \mathrm{L}$ TDS, electrical conductivity of $1280 \mu \mathrm{S} / \mathrm{cm}$ and $\mathrm{pH}$ of 5.46 before treatment. The initial and final results of the physico chemical properties are summarized in Table 2.

Table 2: The initial and final results of the physico - chemical properties 


\begin{tabular}{|c|c|c|c|c|c|c|c|c|c|}
\hline \multicolumn{2}{|c|}{ Parameter } & \multicolumn{8}{|c|}{ Treatments } \\
\hline & & \multicolumn{2}{|c|}{ T. capensis } & \multicolumn{2}{|c|}{ E.crassipes } & \multicolumn{2}{|c|}{ Controls } & \multicolumn{2}{|c|}{$\begin{array}{l}\text { Distilled water } \\
\text { treatments }\end{array}$} \\
\hline & & $\begin{array}{l}100 \% \\
\text { WW }\end{array}$ & $\begin{array}{l}50 \% \\
\text { WW }\end{array}$ & $\begin{array}{l}100 \% \\
\text { WW }\end{array}$ & $\begin{array}{l}50 \% \\
W W\end{array}$ & $\begin{array}{c}\text { Waste } \\
\text { water } \\
\text { only }\end{array}$ & $\begin{array}{c}\text { Waste } \\
\text { water + } \\
\text { soil }\end{array}$ & $\begin{array}{c}\mathrm{DW}+ \\
\text { Eich. spp }\end{array}$ & $\begin{array}{c}\mathrm{DW}+ \\
\text { soil+ Typ. } \\
\text { spp }\end{array}$ \\
\hline \multirow{3}{*}{$\begin{array}{l}\text { TDS in } \\
\mathrm{mg} / \mathrm{L}\end{array}$} & Initial & $\begin{array}{l}1591 \pm \\
1\end{array}$ & $971 \pm 2$ & $\begin{array}{l}1442 \pm \\
1\end{array}$ & $874 \pm 2$ & $1442 \pm 3$ & $1591 \pm 5$ & $4.5 \pm 0.4$ & $313 \pm 3$ \\
\hline & final & $\begin{array}{l}493 \pm \\
2\end{array}$ & $\begin{array}{l}223 \pm \\
4\end{array}$ & $609 \pm 7$ & $305 \pm 6$ & $1370 \pm 3$ & $921 \pm 2$ & $10 \pm 0.8$ & $137 \pm 5$ \\
\hline & $\%$ change & -69.3 & -77.3 & -57.8 & -65.1 & -5.0 & -42.1 & +122.2 & -56.2 \\
\hline \multirow{3}{*}{$\begin{array}{l}\mathbf{E C} \text { in } \\
\mu \mathrm{S} / \mathrm{cm}\end{array}$} & Initial & $\begin{array}{l}1520 \pm \\
4\end{array}$ & $\begin{array}{l}830 \pm \\
3\end{array}$ & $\begin{array}{l}1276 \pm \\
3\end{array}$ & $723 \pm 4$ & $1270 \pm 4$ & $1520 \pm 3$ & $3.7 \pm 0.5$ & $277 \pm 5$ \\
\hline & final & $\begin{array}{l}480 \pm \\
4\end{array}$ & $\begin{array}{l}394 \pm \\
1\end{array}$ & $540 \pm 4$ & $407 \pm 5$ & $1060 \pm 4$ & $857 \pm 2$ & $8.9 \pm 0.4$ & $98 \pm 4$ \\
\hline & $\%$ change & -68.0 & -52.5 & -57.7 & -43.7 & -16.5 & -43.6 & +140.5 & -64.6 \\
\hline \multirow[t]{3}{*}{ pH } & Initial & $\begin{array}{l}5.92 \pm \\
0.03\end{array}$ & $\begin{array}{l}6.25 \pm \\
0.02\end{array}$ & $\begin{array}{l}5.92 \pm \\
0.02\end{array}$ & $\begin{array}{l}6.06 \pm \\
0.02\end{array}$ & $\begin{array}{l}5.45 \pm \\
0.02\end{array}$ & $\begin{array}{l}5.38 \pm \\
0.01\end{array}$ & $7.04 \pm 0.02$ & $\begin{array}{l}6.82 \pm \\
0.02\end{array}$ \\
\hline & final & $\begin{array}{l}7.44 \pm \\
0.01\end{array}$ & $\begin{array}{l}7.66 \pm \\
0.02\end{array}$ & $\begin{array}{l}7.53 \pm \\
0.03\end{array}$ & $\begin{array}{l}7.69 \pm \\
0.02\end{array}$ & $\begin{array}{l}6.48 \pm \\
0.01\end{array}$ & $\begin{array}{l}6.53 \pm \\
0.01\end{array}$ & $7.85 \pm 0.02$ & $\begin{array}{l}7.89 \pm \\
0.02\end{array}$ \\
\hline & $\%$ change & +25.7 & +12.3 & +27.1 & +26.9 & +18.9 & +21.4 & +11.9 & +15.7 \\
\hline
\end{tabular}

Fig. 2 shows the variations of TDS from different treatments over 15 days. TDS decreased significantly (p $<0.05$ ) in both diluted and undiluted effluent in both T.capensis and E.crassipes treatments. On treatment with T.capensis the diluted effluent TDS showed $77.3 \%$ decrease whereas in undiluted there was $69.3 \%$ decrease.

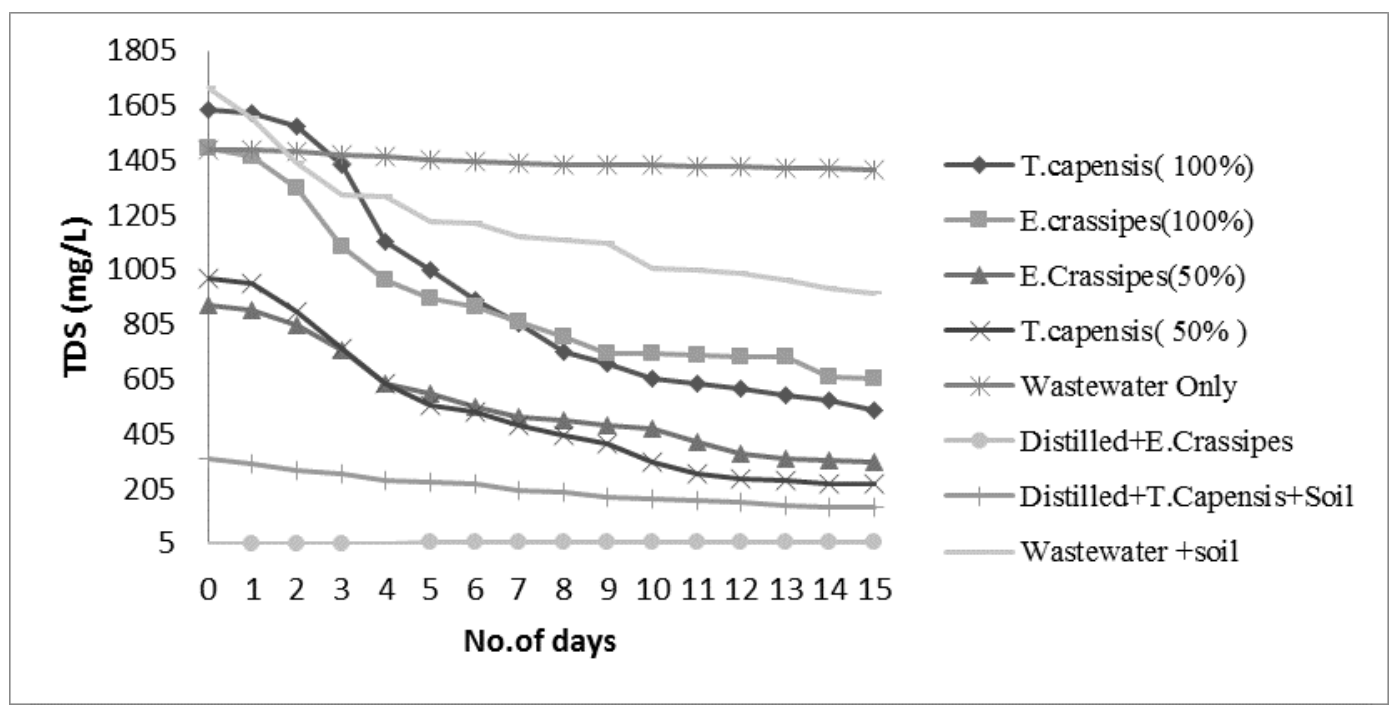

Figure 2: TDS removal from different treatments

The distilled water - soil and T. capensis treatment showed a decrease in TDS of 56.2\%. Wastewater treated with E.crassipes, showed a pronounced reduction in TDS for both diluted $(65.1 \%)$ and undiluted $(57.8 \%)$ effluent. In case of distilled water the E.crassipes treatment showed a slight increase TDS from $4.5 \mathrm{mg} / \mathrm{L}$ to 10 $\mathrm{mg} / \mathrm{L}$. The TDS for wastewater only and wastewater + soil controls was reduced by $5 \%$ and $42.1 \%$ to 1370 $\mathrm{mg} / \mathrm{L}$ and $921 \mathrm{mg} / \mathrm{L}$ after 15 days of treatment respectively. The reduction of TDS in the control experiments can be attributed to microbial activity. Both plants showed better TDS removal in diluted effluent at $\mathrm{p}<0.05$ 
However the decrease of $42.1 \%$ in TDS in wastewater + soil control experiments can also mean that the TDS removal values of $77.3 \%$ for diluted effluent and $69.3 \%$ for undiluted include microbial activity. When this is considered it has less phytoremediation capacity. However, still, the results are comparable to those obtained by [8], who observed a 77\% reduction of TDS in undiluted dairy effluent by Typha species in a constructed wetland. The remaining TDS can be reduced further by using young plants and longer treatment time. The high TDS in T. capensis distilled water + soil treatment can be attributed to the soil added (the soil had $\mathrm{pH}$ of 5.39 and EC $1080 \mu \mathrm{S} / \mathrm{cm}$. However in the distilled water and E.crassipes treatment TDS rose increased mainly because of the release of sugars into the water as osmotic balance mechanism [8].

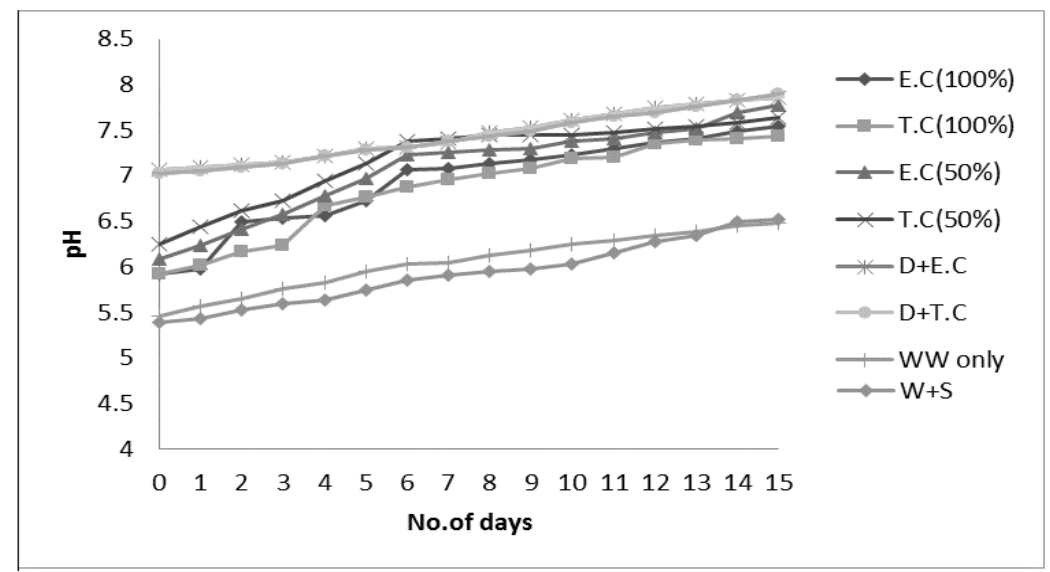

Figure 3: $p H$ variation of treatments with days.

Figure 3 shows the $\mathrm{pH}$ variation of the treatments over 15 days. It is shown that $\mathrm{pH}$ increased by $25.7 \%$ and $12.3 \%$ for undiluted and diluted effluent $(\mathrm{p}<0.05)$ after 15 days of treatment with T.capensis. The $\mathrm{pH}$ of distilled water and T.capensis control also increased by 11\%. It is also shown in Fig. 3 and Table 2 that the pH of undiluted and diluted wastewater treated using E.crassipes also increased by $27.1 \%$ and $26.9 \%$ respectively. The distilled water E. crassipes treatment showed a percentage increase of $11.9 \%$. The pH of wastewater only showed a $\mathrm{pH}$ decreased by $18.9 \%$ whilst that of wastewater and soil was $21.4 \%$. There was significant difference of $\mathrm{pH}$ amongst treatments at $\mathrm{p}<0.05$. The $\mathrm{pH}$ levels of this study increase from acidic to nearly neutral, whereas Dipu et. al. [8] study reduces $\mathrm{pH}$ from alkaline to neutral. The reasons of these difference levels of $\mathrm{pH}$ between the studies can be attributed to different physico-chemical characteristics of dairy and plastic wastewater. Dairy industry uses a lot of disinfectants during their industrial processes [16].

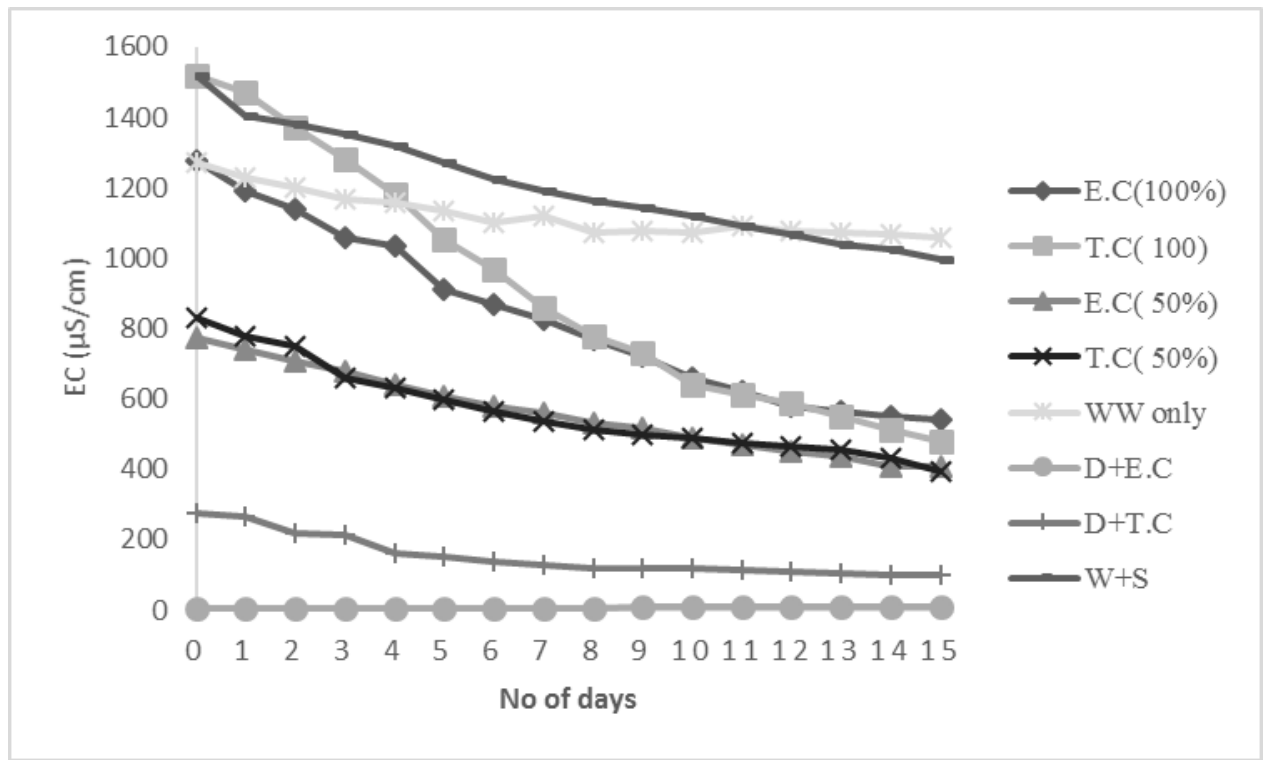

Figure 4: Electrical Conductivity variation of treatments with days

Fig. 4 and Table 2 shows the electrical conductivity variations of treatments with days. The electrical conductivity showed a significant decrease (at $\mathrm{p}<0.05$ ) on treatment with both plants. Electrical conductivity 
decreased by $68.0 \%$ and $52.5 \%$ on treatment of undiluted and diluted effluent with T.capensis respectively. In the E.crassipes treatments the electrical conductivity decreased by $57.7 \%$ and $43.7 \%$ for undiluted and diluted effluent respectively. The reduction of electrical conductivity can have been attributed by the removal of TDS and increase in $\mathrm{pH}$. The results shows trend similar to TDS removal for all the treatments and controls.

The EC/TDS ratio ranged from 0.72 to 0.95 with most falling at 0.88 . However statistical analysis show that there is no significant difference $(\mathrm{p}=0.00)$ between the E.crassipes and T.capensis phytoremediation capacity. The experimental plants have extensive root system which makes them suitable for nutrient uptake. The effluent become clearer from dark brown on treatment with the macropyhtes.

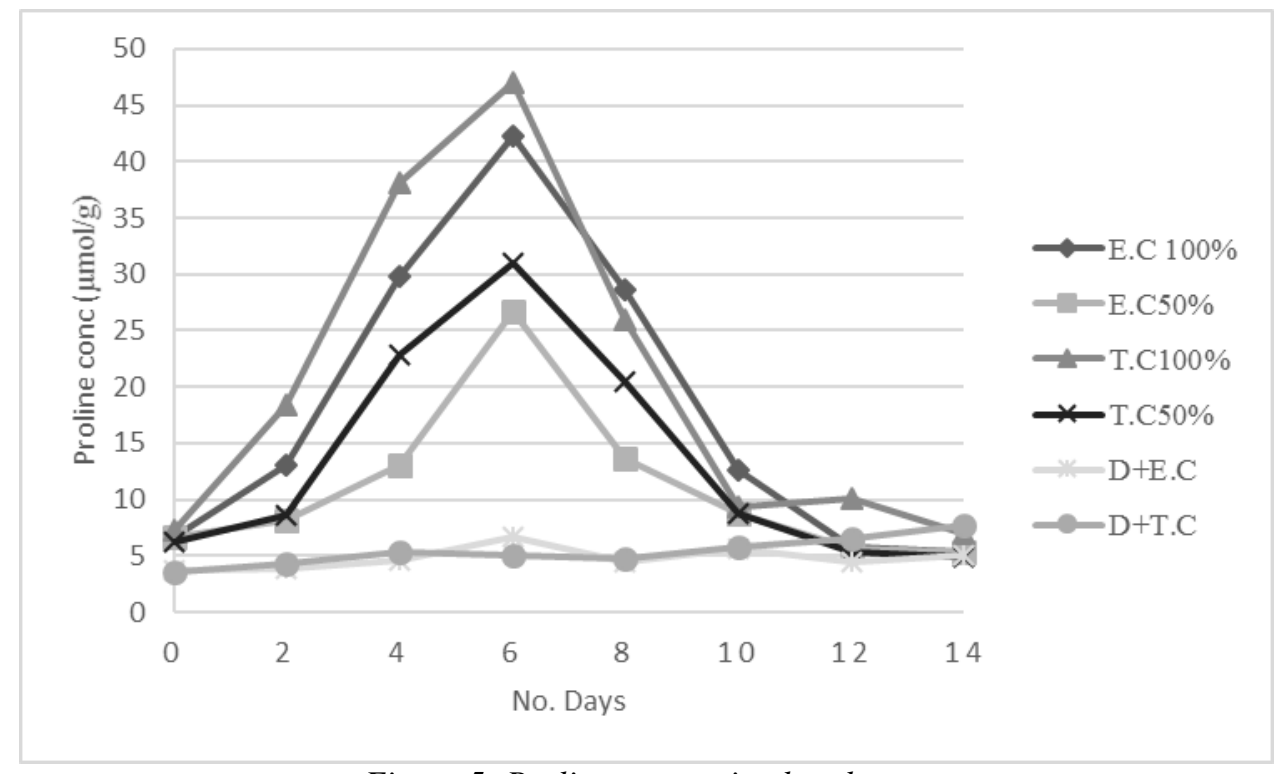

Figure 5: Proline content in plant leaves

Fig. 5 shows that proline concentration increased in the plant leaves from day 0 up to $6-7$ days and decreased to normal around the day 10. Proline accumulation of the two plant species showed a significant difference ( $\mathrm{p}<$ 0.05 ) after 6 days of treatment compared to day 0 as i shown in Fig 5. T.capensis showed an increase in proline after the treatment of undiluted effluent (30.05\%) and diluted effluent (12.50\%). A similar trend was shown in E.crassipes where proline increased in both undiluted (19.04\%) and diluted effluent (11.11\%). However distilled water and plant treatments showed a negligible increase proline concentration. However, there was significant difference for proline accumulation of plant species in different wastewater treatment at $\mathrm{p}<0.05$. T.capensis as an emerging plant showed that it was more stressed as it produced more proline $47 \mu \mathrm{mol} / \mathrm{g}$ compared to $31 \mu \mathrm{mol} / \mathrm{g}$ by E.crassipes for undiluted effluent. The diluted effluent treatments showed a similar trend in which the proline accumulation reached 42 and $27 \mu \mathrm{mol} / \mathrm{g}$ for T.capensis and E. crassipes respectively. The proline accumulation results show that both plants release proline as stress tolerance mechanism to ensure survival in saline conditions. Survival is a prime requirement for phytoremediation.

\section{CONCLUSION}

The results obtained in the study showed that macrophytic plants could remediate wastewater contaminated with high TDS. There was no significant difference between the two plant species tested for wastewater treatment with high TDS, EC and low $\mathrm{pH}$ at $\mathrm{p}<0.05$. The plants showed significant TDS decrease for both undiluted effluent and undiluted effluent. The proline accumulation experiments showed that $T$. capensis accumulated more proline compared to E.crassipes hence was more stressed by the high TDS concentration. However the proline accumulation results show that both plants release proline as stress tolerance mechanism to ensure survival in saline conditions and hence have similar phytoremediation capabilities. It is recommended that similar experiments be done with locally available halophytic plants species such as Digitaria Longiflora for remediation of high TDS, EC and low pH from industrial wastewater. An assessment of how young plants (seedlings) of the same species can perform for a period more than 15 days may shed more light on maximum remediation capability.

\section{Acknowledgements}


The researchers would like to thank Bindura University Chemistry and Environmental Science Technicians for their kind assistance.

\section{REFERENCES}

[1] Fawzy M.A.,Badi N.E.,El-Khatib A. and Abo-El-Kaseem A. (2012),Heavy metal biomonitoring and phytoremediation potentials of aquatic macrophytes in River Nile ,Environ Monit Assess $184: 17531771$

[2] C.A., Basha, P.K. Ghosh, and G. Gajalakshi, Total dissolved solids removal by electrochemical ion exchange (EIX) process. Electrochemical Acta 54,2008, 474-483

[3] S.Saiyood, A.S.Vangnai, D.Inthorn and P. Thiravetyan, Treatment of Total Dissolved Solids from plastic industrial effluent by Halophytic plants, Water Air Soil Pollution 223, 2012,4865-4873

[4] Y.M.F. Marickar Electrical conductivity and total dissolved solids in urine Urol Res 38,2010, 233-235 :DOI 10.1007/s00240-0090228-y

[5] S.R. Pandey,V. Jegatheesan, K. Baskaran Li Shu (2012) Fouling in reverse osmosis (RO) membrane in water recovery from secondary effluent: a review Rev Environ Sci Biotechnol (2012) 11:125-145 DOI 10.1007/s11157-012-9272-0

[6] S.A. Naqvi, M. Kying and M. Kim,A case study on the relationship between conductivity and dissolved solids to evaluate The potential for reuse of reclaimed industrial wastewater KSCE Journal of Civil Engineering 16( 5), 2012,708-713

[7] K.Phyllis, W. Scannell and L. K. Dufy, , Effects of Total Dissolved Solids on Aquatic organisms, American Journal of Environmental Sciences 3(1),2007, 1-6

[8] S.Dipu, A.Anju, V. Kumar and S. G.Thanga, Phytoremediation of dairy effluent by constructed wetland technology, Environmentalist 31,2011,263-278

[9] L.T.Fox,P.C. Struik,B.L. Appleit and J.H.Rule,Nitrogen Phytoremediation by Water Hyacinth (Eichhornia crassipes ),Water Air Soil Poll 7, 2008 199-207

[10] M. Vaclavikova, G. P. Gallios, S.Hredzak, S.Jakabsky, Removal of arseni from water streams: an overview of available techniques. Clean Technologies and Environmental Policy, vol. 10 (1), 2008, 89-95.

[11] L. Pirlak \& A. Eşitken, Salinity effects on growth, proline and ion accumulation in strawberry plants, Acta Agriculturae Scandinavica, Section B - Soil \& Plant Science, 54:3, 2004,189-192, DOI:10.1080/0906471040030249

[12] J. M. Phang, W. Liu, and O.Zabirnyk, 2010Proline Metabolism and Microenvironmental Stress Annu. Rev. Nutr. 2010. 30:441-63

[13] L. S.Bates, R.P. Waldren, and I.D. Teare, Rapid determination of free proline for water- stress studies. Plant and soil 39, 1973,205-207

[14] Claussen W. (2005), Proline as a measure of stress in tomato plants, Plant Science 168:241-245

[15] S.S.M.Naqvi, S. Mumtaz, A.Shereen and M.A.Khan,Comparative performance of two methods for proline estimation in wheat Pak.J.Bot.,34(4):2002, 355-358,

[16] J. S.Sudarson,D. Thatta and A. Das,Phytoremediation of Dairy wastewater using constructed wetlands, Int Pharm Bio Scie, 3( 3), $2012,745-755$ 